\title{
KONTRIBUSI SELF-REGULATED LEARNING DAN KECERDASAN EMOSI DALAM KONSENTRASI BELAJAR
}

\author{
Putri Saraswati \\ Universitas Muhammadiyah Malang \\ putrisaraswati.mpsi@yahoo.com
}

\begin{abstract}
Abstrak
Penelitian ini bertujuan untuk mengetahui hubungan dan kontribusi antara self regulated learning, dan kecerdasan emosi terhadap konsentrasi belajar. Dalam penelitian ini yang dimaksud dengan konsentrasi belajar adalah perhatian seseorang dalam proses belajar. Terdapat beberapa hal yang mempengaruhi konsentrasi seseorang dalam belajar. Hal yang mempengaruhi konsentrasi belajar dapat berasal dari dalam diri maupun dari luar diri seseorang. Dari dalam diri dapat berupa self regulated learning yakni kemampuan seseorang dalam mengevaluasi diri, mengatur, melakukan dan memonitoring hal-hal yang berhubungan dengan proses belajarnya. Selain itu, faktor internal lain yang berhubungan dalam konsentrasi belajar adalah emosi. Kecerdasan emosi adalah kemampuan seseorang dalam mengelola emosinya dan memahami emosi orang lain. Penelitian ini menggunakan metode penelitian kuantitatif korelasional dengan subjek penelitian berjumlah 222 orang yang terdiri dari 66 mahasiswa dan 156 mahasiswi. Teknik sampling yang digunakan adalah stratified random sampling. Data penelitian diambil dengan menggunakan skala likert untuk semua variabelnya. Kemudian diuji dengan teknik statistik korelasi product moment. Hasil penelitian ini adalah 1) tidak ada hubungan antara self regulated learning dan konsentrasi belajar $r=-0.079(p>0,05), 2)$ tidak ada hubungan anatara kecerdasan emosi dan konsentrasi belajar $r=0,677(p>0,05), 3)$ terdapat hubungan positif antara self regulated learning dan kecerdasan emosi $r=0,496(p<0,05)$. Dengan demikian, berarti semakin tinggi self regulated learning maupun kecerdasan emosi yang dimiliki seseorang tidak berhubungan secara signifikan dengan konsentrasi belajar yang dimilikinya. Oleh karena itu, self regulated learning dan kecerdasan emosi tidak memiliki kontribusi yang signifikan terhadap konsentrasi belajar pada penelitian ini.
\end{abstract}

Kata kunci: self regulated learning, kecerdasan emosi, konsentrasi belajar

\begin{abstract}
This study aims to determine the relationship and contribution between self-regulated learning, and emotional intelligence to the concentration of learning. Concentration of learning is a person's attention in the learning process. There are several things that affect a person's concentration in learning. Things that affect the concentration of learning can come from within and from outside a person. From within the self can be self-regulated learning that the ability of a person in self-evaluate, organize, perform and monitor things related to the learning process. In addition, other internal factors that relate in the concentration of learning are emotions. Emotional intelligence is the ability of a person to manage his emotions and understand the emotions of others. This research uses quantitative research method with 222 subjects consisting of 66 students and 156 female students. The sampling technique used is stratified random sampling. The research data is taken using Likert scale for all variables using statistical product moment correlation technique. The result of this research is 1) there is no relation between self regulated learning and learning concentration $r=-0.079(p>0,05)$, 2) there is no correlation between emotional intelligence and learning concentration $r=0,677(p>0,05) 3)$ there is a positive relationship between self regulated learning and emotional intelligence $r=0,496(p<0,05)$. Thus, means that the higher self regulated learning and emotional intelligence owned by a person does not correlate significantly with the concentration of learning it has. Therefore, self regulated learning and emotional intelligence do not have a significant contribution to the concentration of learning in this study.
\end{abstract}

Keywords: self-regulated learning, emotional intelligence, learning concentration

(C) 2016 Universitas Muria Kudus 


\section{PENDAHULUAN}

Latar Belakang

Zimmerman (2002) melihat belajar (learning) sebagai suatu kegiatan yang dilakukan secara pro aktif oleh pelajar untuk mencapai tujuannya dalam pembelajaran. Belajar (learning) dilakukan untuk memperoleh pengetahuan, pemahaman atau kepakaran (Hergenhahn \& Olson, 1993). Untuk mendapatkan pengetahuan, pemahaman dan kepakaran tersebut dibutuhkan usaha. Usaha awal yang dapat dilakukan ialah memberikan fokus perhatian saat belajar. Perhatian dalam penelitian ini adalah konsentrasi merupakan hal yang penting dalam. Dengan memberikan perhatian maka apa yang sedang dipelajari akan lebih mudah diingat oleh otak. Perhatian dalam belajar akan membuat seseorang lebih mudah menyimpan informasi dalam memori dan mengulangnya kembali dalam penyelesaian tugas.

Perhatian yang baik dalam belajar akan membantu seseorang untuk meraih prestasi belajar. Jika seseorang mampu memberikan perhatiaannya pada materi yang disampaikan di kelas, buku yang dibaca dan tugas yang dikerjakan serta fokus untuk mengatasi kesulitankesulitan yang dialaminya dalam belajar, maka ia akan memperoleh hasil belajar sesuai dengan usahanya. Sebagai contoh, berdasarkan hasil observasi peneliti, seseorang yang memberikan fokus perhatian yang baik dalam megerjakan soal ujian, ia akan lebih mudah menyelesaikannya dibandingkan dengan yang melamun. Seseorang yang fokus perhatiaannya tertuju pada materi pelajaran di kelas, ia akan lebih mudah memahami dan ingat materi tersebut.

Sementara perhatian yang kurang saat belajar akan membuat seseorang mengalami kesulitan dalam menyelesaikan tugas-tugas akademiknya dan akan lebih sulit untuk memperoleh prestasi akademik yang baik. Berdasarkan hasil pengamatan peneliti di kelas, peneliti melihat beberapa mahasiswa yang kurang tertarik atau terlihat bosan saat belajar di kelas. Mahasiswa biasanya mengalihkan perhatian belajarnya dengan menggambar, berbicara dengan teman di sebelahnya, atau bermain dengan handphone. Hal ini membuat mahasiswa menjadi kurang paham dengan materi yang sedang dipelajarinya. Terbukti dari ketidakmampuan mahasiswa dalam menjawab pertanyaan dosen.

Perhatian sendiri didefinisikan sebagai suatu proses selektivitas, melakukan sesuatu dalam perilaku memberi perhatian (Mole, 2011). Perhatian melibatan proses berpikir dalam diri seseorang. Bradley menyatakan bahwa suatu aktivitas dikatakan menarik perhatian jika dan hanya jika seseorang memberikan seluruh perhatiannya dan berusaha untuk memberikan ketertarikannya (Mole, 2011). Hal ini berarti, untuk dapat memberikan fokus perhatian dalam belajar, seseorang perlu berusaha dan mencoba untuk tertarik dan memusatkan seluruh perhatiannya untuk belajar. 
Terdapat beberapa hal yang berhubungan dengan perhatian (konsentrasi) yakni kecerdasan, regulasi diri dan regulasi emosi (Vroon \& Stelmach, 1990). Menurut Vroon \& Stelmach (1990) bayi yang memberikan perhatian pada stimulus tertentu melibatkan keterampilan sensori (Johnson \& Brody, 1977), kemampuan dalam mengeksplorasi lingkungan dengan cepat (Fenson, Sapper, \& Minner, 1974; Messer, Kagan, \& McCall, 1970; Pecheux \& Lecuyer, 1983); kemampuan pengambilan keputusan (Lewis, Goldberg, \& Campbell, 1969), dan menampilkan kemampuannya dalam mengidentifikasi, mencocokkan gambar dan balok dalam tes inteligensi tradisional (Miller,Spiridigliozzi, Ryan, Callan, \& McLaughlin, 1980). Berdasarkan penelitian ini dapat dipahami bahwa perhatian berhubungan dengan inteligensi yang dimiliki seseorang yang didalamnya meliputi kemampuan dalam mengabil keputusan, koordinasi motorik, rasa ingin tahu terhadap lingkungan.

Selanjutnya, faktor lain yang mempengaruhi perhatian adalah regulasi diri. Menurut Posner \& Rothbart dalam penelitiannya di tahun 1981, perhatian adalah dasar dari regulasi diri (Vroon \& Stelmach, 1990). Sistem perhatian di otak memberikan dasar bagi regulasi diri. Beberapa bayi menunjukkan reaksi yang kuat pada peristiwa ekternal, seperti mudah menangis, waspada terhadap hal baru, namun beberapa bayi lain tidak (Rothbart, 1989; Rothbart \& Mauro, in press dalam Vroon \& Stelmach, 1990). Dapat disimpulkan bahwa perhatian berhubungan dengan kemampuan seseorang dalam mengatur, mengendalikan, dan mengevaluasi dirinya atau disebut sebagai regulasi diri. Sementara itu, menurut Luria yang sejalan dengan pendapat Vygotsky, bahwa perhatian seseorang lebih dipegaruhi oleh kondisi lingkungan di sekitarnya dibanding dengan kondisi biologis (Vroon \& Stelmch, 1990). Bagaimana perhatian dipengaruhi oleh budaya seseorang. Bagaimana gaya bicara seseorang dipengaruhi oleh kelompoknya. Hal ini juga mempengaruhi oleh regulasi emosi seseorang (Luria dalam Vroon \& Stelmach, 1990). Menurut Luria kelekatan hubungan bayi dan pengasuhnya mempengruhi reaksi emosinya. la juga berpendapat bayi akan memberikan perhatiannya pada kehadiran dan apa yang dilakukan pengasuhnya, sehingga dari hasil stimulus yang diperhatikan oleh bayi juga dapat memculkan reaksi emosi (Vroon \& Stelmach, 1990). Ketika emosi yang dirasakan bervalensi positif, maka seseorang akan dapat lebih fokus terhadap tugas yang ia kerjakan (Panjaitan \& Cahyadi, nd).

Berdasarkan beberapa penelitian di atas maka dapat dikatakan bahwa perhatian berhubungan dan dipengaruhi oleh kecerdasan, regulasi diri dan emosi. Begitu pula dengan perhatian dalam belajar, dapat dipengaruhi oleh berbagai faktor baik dalam diri maupun dari luar diri. Selain faktor dari luar diri seperti kesehatan fisik, faktor dari dalam diri seperti emosi, motivasi, juga berhubungan dengan perhatian yang dimiliki seseorang.

Selanjutnya, terdapat beberapa cara untuk meningatkan perhatian saat belajar, antara lain memberikan waktu yang jelas dalam menyelesaikan tugas, membuat seseorang tidak terlalu cepat berganti dari satu tugas ke tugas lain dengan membatasi pilihan, mengurangi 
jumlah ganguan dalam ruangan, memberi umpan balik dengan segera memotivasi agar tetap menyelesaikan tugas atau mengarahkan kembali perhatiannya pada tugas yang sedang dikerjakan, merencanakan tugas yang lebih kecil daripada memberikan satu sesi tugas yang panjang, menetapkan tujuan dan menawarkan hadiah untuk memotivasi agar terus belajar (Flanagan dalam Nuryana, 2010).

Beberapa cara di atas dapat dimasukkan ke dalam bagian dari regulasi diri belajar (self-regulated leraning). Self regulated learning (SRL) adalah keaktifan yang dimiliki pelajar (Learner) secara meta kognitif, motivasi dan perilaku dalam proses belajar mereka (Zimmerman, 1986,1989). Self-regulated learning dapat meningkatkan kontrol dan keyakinan diri, sehingga dapat berpengaruh positif terhadap prestasi akademik (academic achievement) (Fuchs et al., 2003; Zimmerman \& Kitsantas, 1999 dalam Hoyle, R.H. (2010). Broadly menyatakan, self regulated learning (SRL) adalah belajar dengan bantuan meta kognisi, pelaksanaan yang berstrategi (perencanaan, monitoring, dan evaluasi perubahan yang dialami dan dibandingkan dengan standar yang ingin dicapai), dan motivasi belajar (Butler \& Winne, 1995; Winne \& Perry, 2000; Perry, Phillips, \& Hutchinson, 2006; Zimmerman, 1990; Boekaerts \& Corno, 2005). Definisi dari self regulated learning adalah "self-oriented feedback" yang bersifat melingkar/siklus (carver \& scheier, 1981), yakni proses yang berputar dimana pelajar (learner) memonitor keefektivan metode/strategi belajar dan reaksi terhadap umpan balik dengan berbagai cara mulai dari perubahan yang tidak tampak dari persepsi diri hingga perubahan yang tampak dalam perilaku. Definisi terakhir dari self regulated learning adalah suatu indikasi bagaimana dan megapa pelajar (learner) memilih strategi atau tujuan tertentu. Dengan kata lain, kemampuan seseorang yang baik dalam mengatur dan mengevaluasi dirinya dalam belajar akan membuatnya lebih fokus dalam menyelesaikan tugasnya sehingga dapat membantu meningkatkan prestasi akademik yang dimilikinya. Regulasi diri dalam belajar disini berarti, seseorang harus mampu mengatur kondisi belajarnya baik diri (kondisi fisik/tubuh dan psikologis/motivasi/pikiran) maupun lingkungannya agar dapat memenuhi target belajar yang diharapkan dan memungkinkan untuk memperbaiki kembali cara yang digunakan jika mengalami kegagalan atau tidak sesuai dengan target yang diharapkan dalam belajar.

Selain Self Regulated Learning (SRL), kemampuan untuk mengatur emosi juga berpengaruh terhadap fokus belajar. Pelajar cenderung tidak tertarik dan menjauhi tugasnya karena menimbulkan emosi yang tidak menyenangkan (Pekrun, 2014). Individu yang memiliki kecerdasan emosional yang baik akan mampu menghadapi tantangan dan mempertahankan semangat hidup (Patton, 1998). Hal ini juga diperkuat dengan hasil penelitian lain yang menyebutkan bahwa regulasi emosi, usaha untuk mengontrol, dan executif function memiliki kontribusi terhadap adaptasi di sekolah dan terhadap prestasi akademik sejak awal (Blair \& Razza, 2007; Howse et al., 2003 (dalam Hoyle, R.H, 2010). 
Penelitian lain menyebutkan bahwa anak yang sulit dalam mengendalikan emosinya maka akan mengalami kesulitan dalam mengendalikan perilakunya di berbagai setting dan sebagai akibatnya ia akan mengalami kesulitan dalam belajar dan kesulitan untuk mendapatkan keterampilan-keterampilan dasar sosial dan kognitif yang dibutuhkan untuk mencapai prestasi akademik (Eisenberg, Sadovsky, \& Spinrad, 2005; Ladd, Herald, \& Kochel, 2006). Sementara itu, anak yang memiliki keterampilan yang baik dalam menjaga mood positif lebih mampu untuk menyelesaikan tugas-tugas sekolah (Kuhl \& Kraska, 1989 dalam Hoyle, R.H., 2010). Menurut Goleman (1995) Kecerdasan emosi lebih penting daripada Kecerdasan Intelektual dalam memprediksi kesuksesan dalam hidup, termasuk dalam kesuksesan akademik (Stough, C., Saklofske, A.H., \& James Parker, D.A., 2009). Oleh karena itu, kecerdasan emosi juga dibutuhkan untuk lebih fokus dalam memberikan perhatian saat belajar. Dengan kemampuan yang baik dalam mengendalikan emosi, membuat seseorang akan lebih mudah dalam menyelesaikan tugas-tugas akademiknya, secara tidak langsung memudahkan seseorang untuk lebih fokus dalam memberikan perhatian saat belajar.

Berdasarkan uraian di atas maka peneliti tertarik untuk melakukan penelitian tentang regulasi diri dalam belajar/Self regulated learning (SLR) dan kecerdasan emosi terhadap perhatian atau konsentrasi dalam belajar. Peneliti ingin mencari jawaban atas beberapa pertanyaan berikut:

1. Apakah terdapat hubungan antara self regulated learning dan kecerdasan terhadap konsentrasi belajar?

2. Besar sumbangan self regulated learning dan kecerdasan emosi terhadap konsentrasi belajar pada mahasiswa?

Dengan demikian peneliti dapat mengetahui hubungan dan besarnya sumbangan self regulated learning (SRL) dan kecerdasan emosi terhadap konsentrasi belajar pada mahasiswa.

Manfaat Penelitian

Penelitian ini, memberikan manfaat kepada beberapa pihak:

1. Bagi Ilmu Psikologi

Mengembangkan ilmu psikologi terutama dalam bidang psikologi pendidikan.

2. Bagi Subjek Penelitian

Meningkatkan kemampuan self regulated learning dan kecerdasan emosi bagi mahasiswa sehingga dapat meningkatkan kemampuan akademik mereka.

3. Bagi Peneliti Selanjutnya

Mengembangkan metode self regulated learning guna mengoptimalkan potensi akademik mahasiswa. 


\section{Attention (Perhatian)}

Kata perhatian biasanya ditujukan untuk proses seleksivitas (James, Wiliam, 1890 dalam Eyesenck \& Keane, 2005). la membedakan perhatian menjadi dua model yakni aktif dan pasif. Perhatian aktif dikontrol oleh motivasi individu, sementara perhatian tipe pasif dikontrol oleh stimulus eksternal (Eyesenck \& Keane, 2005). Dalam penelitian lain, menyebutkan istilah konsentrasi yakni kemampuan memusatkan pemikiran atau kemampuan mental dalam menyortir informasi yang tidak diperlukan dan memusatkan perhatian hanya pada informasi yang dibutuhkan saja (Sugiyanto dalam Helmi, 1995).

Dengan demikian, dapat dikatakan bahwa konsentrasi memiliki makna yang serupa yakni memberikan respon pada stimulus yang dihendaki. Selain itu, dari uraian di atas dapat disimpulkan pula bahwa terdapat perhatian diperngaruhi oleh dua faktor yakni motivasi dan kondisi eksternal. Motivasi adalah tujuan atau dorongan dalam diri seseorang yang menggerakkan seseorang dalam memperhatikan stimulus yang ada. Sementara itu, kondisi ekternal adalah kondisi lingkungan dimana stimulus itu muncul. Menurut Eyesenck \& Keane (2005), terdapat tiga hal yang dapat membatasi atau mempengaruhi perhatian seseorang, antara lain:

1. Lingkungan, baik lingkungan di luar diri maupun lingkungan di dalam diri, seperti pikiran dan informasi di long term memori.

2. Tujuan atau motivasi dalam memperhatikan stimulasi. Dalam banyak penelitian, yang lebih banyak mempengaruhi perhatian adalah instruksi eksperimen dibandingkan motivasi para partisipan eksperimen.

3. Dimensi individu, objek dan perilaku yang sesuai.

Berdasarkan penjabaran definisi dan faktor yang mempengaruhi perhatian di atas, maka dapat disimpulkan bahwa perhatian dalam belajar adalah memberikan respon yang sesuai saat belajar. Perhatian belajar, dapat diartikan lebih dekat maknanya dengan perhatian terfokus terhadap kegiatan atau aktivitas belajar, mulai dari menerima dan memasukkan informasi pada kognitif, mengelolanya hingga mengulangnya kembali dalam bentuk pengerjaan tugas.

Perhatian dapat dikelompokkan menjadi dua yakni perhatian yang terfokus (focused attention) dan perhatian yang terbagi (divided attention) (Eyesenck \& Keane, 2005).

Perhatian yang terbagi (divided attention) adalah sedikitnya dua stimulus yang dihadirkan pada waktu yang sama, namun semua stimulus harus diperhatikan dan direspon. Menurut Eyesenck \& Keane (2005) perhatian yang terbagi (divided attention) dikelompokkan menjadi tiga jenis yakni berdasarkan kesamaan tugas, kesulitan tugas dan kepraktisannya. Sedangkan, perhatian yang terfokus (focused attention) adalah dua atau lebih stimulus yang dihadirkan pada waktu yang sama namun hanya diminta merespon satu stimulus saja 
(Eyesenck \& Keane, 2005). Perhatian terfokus dikelompokkan menjadi dua yaitu auditori dan visual.

\section{Self Regulated Learning (SRL)}

Self regulated Learning adalah dapat digambarkan sebagai keaktifan yang dimiliki pelajar (Learner) secara metakognitif, motivasi dan perilaku dalam proses belajar. Menggunakan strategi metakognisi, motivasi dan atau perilaku adalah karaketeristik dari definisi pertama self regulated learner (Zimmerman, 1986, 1989). Regulasi diri (selfregulation) dalam belajar adalah bagaimana seorang pelajar dapat mengatur pikiran, perasaan, serta tingkah lakunya untuk mencapai tujuan tertentu, yaitu untuk kepentingan akademik (Zimmerman, 2002).

Self-regulation adalah sebuah proses yang terus berputar dan saling mempengaruhi (siklik), yang terdiri dari 3 fase, yaitu forethought, performance, dan self-reflection. Fase pertama (forethought) adalah fase dimana seseorang menentukan tujuan dan menentukan cara atau langkah-langkah yang harus dilakukan untuk mencapai tujuan tersebut. Fase kedua (performance) adalah fase pelaksanaan dari langkah-langkah yang sudah direncanakan, sedang fase ketiga (self-reflection) adalah fase dimana seseorang mengevaluasi proses yang sudah dilakukan, untuk kemudian menentukan apa yang akan ia lakukan selanjutnya untuk dapat mencapai tujuan awal (Panjaitan dan Cahyadi, nd).

Zimmerman (2002) mengajukan 8 strategi self-regulated learner, yaitu : (1) menentukan tujuan yang spesifik, proksimal, serta menantang, (2) mengadopsi strategi yang tepat untuk mencapai tujuan, (3) memantau performa diri secara selektif untuk melihat adanya pengingkatan, (4) menyesuaikan lingkungan fisik dan sosial dengan keadaan seseorang untuk mencapai tujuannya, (5) mengelola waktu secara efisien, (6) mengevaluasi metode yang sudah digunakan, (7) menentukan causal attribution atau menilai penyebab dari hasil yang sudah didapat, serta (8) mengadaptasi metode yang akan digunakan.

\section{Kecerdasan Emosi}

Menurut Goleman (2001) kecerdasan emosi (emotional intelligence) adalah kemampuan untuk mengenali perasaan kita sendiri dan perasaan orang lain, kemampuan memotivasi diri sendiri, dan kemampuan mengelola emosi dengan baik pada diri sendiri dalam hubungan dengan orang lain.

Menurut Salovey dan Mayer (dalam Goleman, 2001), kecerdasan emosional merupakan kemampuan memantau dan mengendalikan perasaan sendiri dan orang lain, serta menggunakan perasaan-perasaan itu untuk memandu pikiran dan tindakan. Individu yang mempunyai kecerdasan emosional yang tinggi akan mampu mengatasi berbagai masalah atau tantangan yang muncul dalam hidupnya. 
Salovey, Hsee and Mayer, (dalam Hewstone, 2005) berpendapat bahwa kecerdasan emosi berfokus pada 1. kebutuhan dan ekspresi emosi, 2. penggunaan informasi berdasarkan emosi dan 3. adaptasi alami dari regulasi emosi.

Salovey dan Mayer (dalam Goleman, 2007) mengungkapkan lima aspek dalam kecerdasan emosional, yaitu: a. Mengenali emosi diri, adalah kemampuan untuk memantau perasaan dari waktu ke waktu dan kemampuan mengenali perasaan sewaktu perasaan itu terjadi; b. Mengelola emosi, adalah kemampuan untuk menguasai perasaannya sendiri agar perasaan tersebut dapat diungkapkan dengan tepat; c. Memotivasi diri sendiri, adalah kemampuan untuk menggerakkan dan menuntun menuju tujuan; $d$. Mengenali emosi orang lain (empati), bukan hanya untuk mengetahui pikirannya saja melainkan juga perasaan orang lain; e. Membina hubungan, adalah kemampuan seseorang untuk membentuk hubungan, membina kedekatan hubungan, sebagian besar merupakan keterampilam mengelola emosi orang lain. Lima aspek kecerdasan emosi tersebut dalam pengukuran intelegensi emosi, dijelaskan sebagai berikut yaitu kemampuan intrapersonal (berisi kemampuan-kemampuan dalam mengenali dan melabel emosi diri), kemampuan interpersonal (berisi kemampuankemampuan dalam mengidentifikasi emosi orang lain dan berempati), adaptabilitas (berisi kemampuan-kemampuan untuk mampu menilai emosi-emosi dan perilaku-perilaku guna mengubah situasi atau kondisi), dan kemampuan dalam menejemen stres (berisi kemampuan seperti menunda atau bertahan terhadap stimulus yang menimbulkan stres)

Salovey dan mahasiswanya berpendapat bahawa self regulasi emosi bergantung pada 2 faktor. Pertama, bagaimana kita mengatur emosi kita. Hal ini bergantung pada kesadaran emosional dan kesadaran pikiran kita tentang mood yang sedang kita rasakan. Kedua, tergantung pada strategi yang dapat digunakan untuk mempengaruhi perasaan kita.

\section{Hubungan Self Regulated Learning, Kecerdasan Emosi dan Konsentrasi Belajar}

Self Regulated Learning (SRL) merupakan kemampuan seseorang untuk memonitor, merencanakan, mengevaluasi diri serta melaksanakan kembali rencana dan antisipasi kegagalan terkait dengan proses pembelajaran. Seseorang yang memiliki kemampuan SRL yang baik akan mampu menonitor dirinya. Individu tersebut dapat mengidentifikasi dan menganalisa kemampuan-kemampuan yang dimilikinya baik kelebihan dan kekurangannya dalam belajar dan memahami pelajaran. Setelah mampu memonitor, individu dengan SRL yang baik akan mampu melakukan perencanaan terhadap proses belajarnya. Individu tersebut mampu memilih tujuan dan strategi belajar yang sesuai dengan gambaran dirinya. Selanjutnya, individu tersebut akan melaksanakan rencana belajarnya dan juga mampu mengevaluasi pelaksaan rencana tersebut. Penilaian diri terkait dengan proses belajar, berhubungan dengan keberhasilan dan kegagalan atas tujua dan strategi belajar yang telah dibuat dan dilaksanakan. 
Penilaian diri atas rencana belajar akan memunculkan keinginan individu untuk mempertahankan atau memperbaiki tujuan dan strategi yang telah dilakukan guna meraih hasil belajar yang diharapkan. Dengan SRL yang baik berarti indivudu memiliki perhatian belajar yang baik sehingga memiliki performa akademik yang baik dan mendapatkan hasil belajar yang baik, begitu juga sebaliknya. SRL yang buruk berarti individu memiliki perhatian yang buruk dalam belajar sehingga akan membuat individu memiliki kualitas belajar yang buruk dan menghasikan nilai atau hasil belajar yang buruk pula. Selain SRL, perhatian belajar dalam hal ini konsentrasi juga dapat dihubungkan dengan kecerdasan emosi.

Kecerdasan emosi yang baik, artinya individu atau seseorang memiliki kemampuan yang baik dalam mengenali emosi diri dan orang lain, mengelola, memotivasi diri serta membina hubungan dengan orang lain. Individu yang mampu mengenali emosi diri dan orang lain, berarti mampu mengidentifikasi perasaan yang dirasakan dirinya dan orang lain. Kecerdasan emosi yang baik tidak sekedar mengenali emosi namun juga mengelola emosi dan memotivasi diri agar dapat mencapai tujuannya serta mampu menjalin hubungan dan mempertahankan hubungan tersebut. Oleh karena itu, individu yang memiliki kemampuan yang baik dalam mengindentifikasi perasaan diri, orang lain saat belajar, kemudian mengelolanya serta mampu memotivasi dirinya agar tetap mampu meraih tujuan dalam belajar dan mampu membina hubungan dengan orang-orang yang terlibat dalam proses belajarnya, maka individu tersebut akan lebih mampu memberikan fokus perhatian dalam belajar sehingga mampu memberikan performa akademik dan hasil belajar yang baik. Begitu juga sebaliknya, individu yang tidak mampu mengenali emosinya, mengelola emosi dan memotivasi diri dalam belajar serta membina hubungan yang hangat dengan orang lain, maka perhatiannya akan lebih banyak terfokus dengan masalah dan emosinya bukan pada belajarnya. Hal ini membuat perhatian belajarnya menurun sehingga performa akademik dan hasil belajarnya juga berkurang.

\section{Bagan 2.1. Kerangka Teoritis}

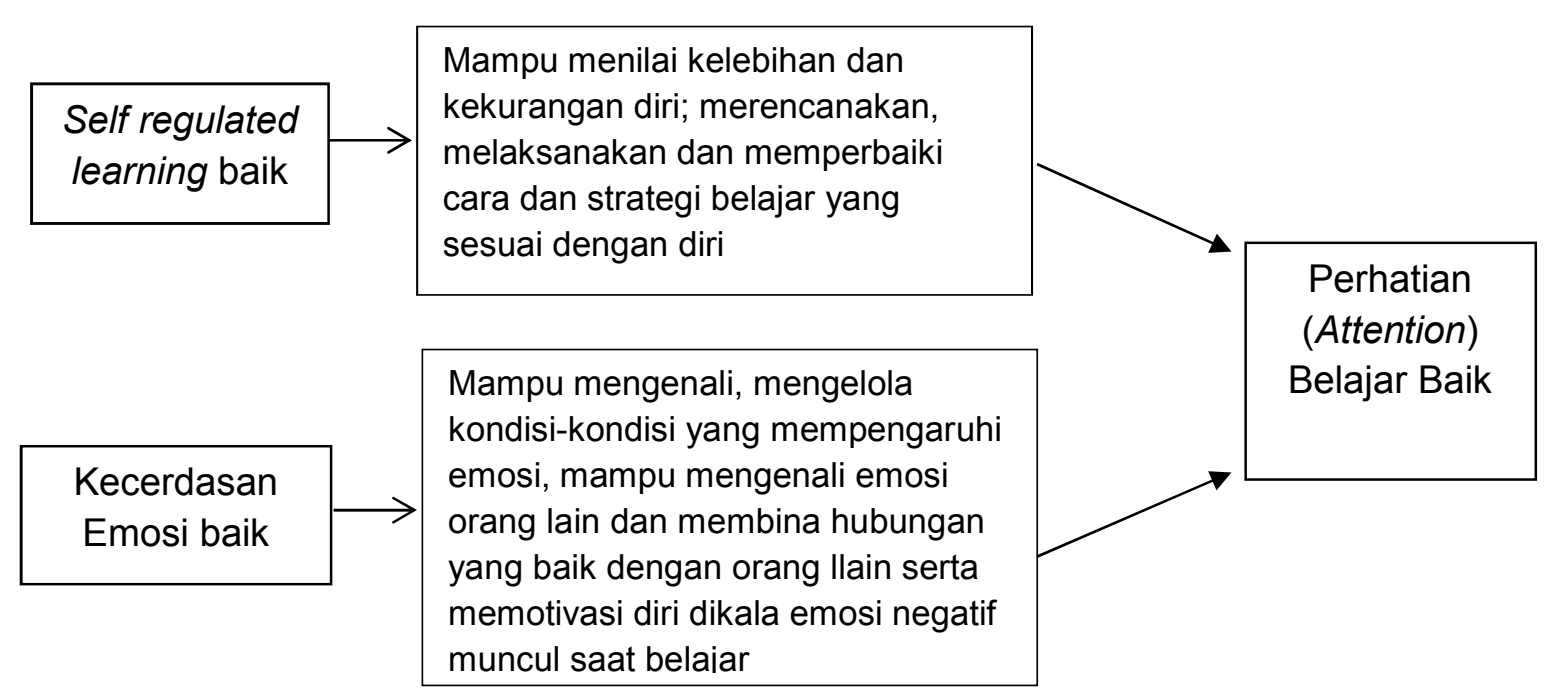




\section{Hipotesa Penelitian}

Pada penelitian ini hipotesa yang diberikan peneliti adalah terdapat hubungan antara self regulated learning dan kecerdasan emosi terhadap konsentrasi belajar.

\section{Metode Penelitian}

Jenis penelitian

Jenis penelitian yang digunakan dalam penelitian ini adalah penelitian kuantitatif korelasional. Penelitian ini mempelajari hubungan dua variabel atau lebih, yakni sejauhmana variasi dalam satu variabel berhubungan dengan variasi dalam variabel yang lain (Noor, 2014).

\section{Populasi dan Sample}

Karakteristik populasi pada penelitian ini adalah sebagai berikut:

a. Mahasiswa Psikologi di Universitas Muhammadiyah Malang

b. Telah mengikuti perkuliahan selama minimal 1 semester

c. Memiliki penilaian hasil belajar dari dosen yang berupa IP

d. Berada pada tingkat 1, 2 dan 3

Sampel pada penelitian ini diambil dengan cara stratified random sampling yakni sampel yang diambil dengan cara acak berdasarkan tingkatannya. Hal ini disebabkan karena populasi pada penelitian ini memilliki tingkatan dan masing-masing tingkatan memiliki kesempatan yang sama untuk dipilih menjadi subjek penelitian. Menurut Winarsunu (2002) apabila populasi terdiri dari kategori-kategori yang mempunyai susunan bertingkat dan diduga tingkatan tersebut berpengaruh pada variabel yang diteliti. Jumlah subjek dalam penelitian ini ditentukan dengan menggunakan tabel Krejcie dan Morgan (Noor, 2014), dari populasi sejumlah 900 maka sampel yang diambil sejumlah 265. Dari 265 skala yang disebarkan hanya 236 yang kembali dan 222 yang dapat dianalisa, sebab subjek tidak menjawab seluruh pernyataan dalam skala tersebut.

\section{Teknik Pengumpulan data}

Data dalam penelitian ini dikumpulkan dengan cara membagikan skala psikologis dalam bentuk likert. Skala ini terdiri dari skala tentang perhatian dalam belajar, skala self regulated learning dan skala kecerdasan emosi. Pada masing-masing skala memiliki empat pilihan jawaban, yaitu sangat sesuai menggambarkan diri partisipan, sesuai menggambarkan diri partisipan, kurang sesuai menggambarkan diri partisipan dan tidak sesuai dalam menggambarkan diri partisipan. 
Pada Skala self regulated learning berisi beberapa indikator yang turun dari aspek kognitif, aspek motivasional dan aspek behavioral. Skala self regulated learning ini diambil dari skala Elpidia (2014) dengan reliabilitas sebesar 0.992.

Sementara itu, Skala kecerdasan emosional disusun dari beberapa aspek utama yang sesuai dengan teori Danil Goleman, yakni 1. Mengenali emosi, 2. Mengelola emosi, 3. Memotivasi diri, 4. Mengenali emosi orang lain (berempati), dan 5. Membina hubungan yang baik dengan orang lain. Skala ini menggunakan skala kecerdasan emosi Drastiana (2016), dengan nilai reliabilitas sebesar 0,928 dan validitas item sebesar 0,321 - 0,654.

Selanjutnya, skala konsentrasi belajar dibuat dari definisi operasional yakni proses memilih informasi yang diterima seseorang. Skala ini tersusun atas beberapa aspek yakni perhatian yang terbagi dan perhatian yang terfokus. Skala ini dibuat peneliti dengan menggunakan try-out terpakai. Skala ini memiliki reliabilitas sebesar 0,798 dan validitas item sebesar $0,250-0,539$.

Teknik Analisa Data

Data yang telah diperoleh dalam penelitian ini, dilakukan analisa dengan menggunakan teknik analisa product moment. Dalam pelaksanaan teknisnya, peneliti akan menggunakan software SPSS.

\section{Hasil dan Pembahasan}

Hasil Penelitian

Hasil penelitian yang diperoleh dari data sampel sebanyak 222 orang mahasiswa, dapat dipaparkan dalam tabel di bawah ini:

Tabel 4.1.1. Karakterikstik subjek

\begin{tabular}{ccc}
\hline Kategori & Kelompok & Jumlah \\
\hline Jenis Kelamin & Laki-laki & 66 \\
& Perempuan & 156 \\
\hline Usia & 17 & 2 \\
& 18 & 42 \\
& 19 & 68 \\
20 & 70 \\
& 21 & 34 \\
& 22 & 4 \\
& 23 & 1 \\
\hline Angkatan & 2014 & 64 \\
& 2015 & 73 \\
& 2016 & 85 \\
\hline
\end{tabular}


Berdasarkan tabel di atas, dapat diketahui bahwa subjek penelitian sebanyak 222 mahasiswa dengan mayoritas berjenis kelamin perempuan sebanyak 156 dan sisanya berjenis kelamin laki-laki sebanyak 66 mahasiswa. Selain itu, dari tabel di atas dapat dilihat bahwa mayoritas subjek penelitian berusia 19 hingga 20 tahun dan subjek yang berusia 23 tahun hanya berjumlah 1 orang. Bila dilihat dari angkatan, subjek penelitian ini didominasi oleh mahasiswa angkatan 2016, diikuti dengan mahasiswa angkatan 2015 dan terakhir angkatan 2014, yakni tingkat 1, 2 dan 3.

Tabel 4.1.2. Uji normalitas kecerdasan emosi

\begin{tabular}{|c|c|c|c|c|}
\hline \multicolumn{5}{|c|}{ One-Sample Kolmogorov-Smirnov Test } \\
\hline & & $\begin{array}{c}\text { kecerdasan_e } \\
\text { mosi }\end{array}$ & SLR & $\begin{array}{c}\text { konsentrasi_b } \\
\text { elajar }\end{array}$ \\
\hline \multicolumn{2}{|l|}{$\mathrm{N}$} & 222 & 222 & 222 \\
\hline \multirow{2}{*}{ Normal Parameters ${ }^{a, b}$} & Mean & 105,93 & 221,90 & 51,53 \\
\hline & Std. Deviation & 6,903 & 18,504 & 6,685 \\
\hline \multirow{3}{*}{$\begin{array}{l}\text { Most Extreme } \\
\text { Differences }\end{array}$} & Absolute & ,065 & ,088 & ,078 \\
\hline & Positive & ,065 & ,088 & ,076 \\
\hline & Negative &,- 064 &,- 055 &,- 078 \\
\hline \multicolumn{2}{|l|}{ Kolmogorov-Smirnov Z } & 971 & 1,311 & 1,161 \\
\hline \multicolumn{2}{|l|}{ Asymp. Sig. (2-tailed) } & ,302 &, 064 & ,135 \\
\hline \multicolumn{5}{|c|}{ a. Test distribution is Normal. } \\
\hline \multicolumn{2}{|l|}{ b. Calculated from data. } & & & \\
\hline
\end{tabular}

Berdasarkan tabel di atas dapat diketahui bahwa nilai signifikansi varibel kecerdasan emosi sebesar 0,302 ( $p>0.05$ ). Hal ini berarti data kecerdasan emosi memiliki distribusi yang normal. Sedangkan nilai signifikansi Self regulated Learning adalah sebesar 0,064 ( $p>0.05)$. Hal ini berarti data self regulatd learning memiliki distribusi yang normal. Selanjutnya, data pada variabel konsentrasi belajar juga berdistribusi normal. Hal ini terlihat dari nilai signifikansinya sebesar 0.135 ( $p>0.05)$.

Tabel 4.1.3. Uji linieritas konsentrasi belajar dan SLR

\begin{tabular}{|c|c|c|c|c|c|c|c|}
\hline \multicolumn{8}{|c|}{ ANOVA Table (baru) } \\
\hline & & & Sum of Squares & df & Mean Square & $\mathrm{F}$ & Sig. \\
\hline \multirow{5}{*}{$\begin{array}{l}\text { konsentrasi_belajar } \\
\text { * SLR }\end{array}$} & & (Combined) & 3099,542 & 70 & 44,279 & ,986 &, 516 \\
\hline & Between & Linearity & 61,447 & 1 & 61,447 & 1,369 & ,244 \\
\hline & Groups & $\begin{array}{l}\text { Deviation from } \\
\text { Linearity }\end{array}$ & 3038,095 & 69 & 44,030 & ,981 & ,527 \\
\hline & Within $\mathrm{Gr}$ & ups & 6777,737 & 151 & 44,886 & & \\
\hline & Total & & 9877,279 & 221 & & & \\
\hline
\end{tabular}


Berdasarkan tabel di atas dapat diketahui bahwa nilai signifikansi sebesar 0,527. Nilai ini lebih besar dari 0,05. Hal ini berarti data self regulated learning bersifat linier.

Tabel 4.1.4. Uji linieritas konsentrasi belajar dan kecerdasan emosi

\begin{tabular}{|c|c|c|c|c|c|c|c|}
\hline \multicolumn{8}{|c|}{ ANOVA Table (baru) } \\
\hline & & & Sum of Squares & df & $\begin{array}{l}\text { Mean } \\
\text { Square }\end{array}$ & $\mathrm{F}$ & Sig. \\
\hline \multirow{5}{*}{$\begin{array}{l}\text { konsentrasi_belaj } \\
\text { ar * } \\
\text { kecerdasan_emo } \\
\text { si }\end{array}$} & & (Combined) & 2048,995 & 34 & 60,265 & 1,440 & ,067 \\
\hline & Between & Linearity & 7,822 & 1 & 7,822 & ,187 & ,666 \\
\hline & Groups & $\begin{array}{l}\text { Deviation from } \\
\text { Linearity }\end{array}$ & 2041,172 & 33 & 61,854 & 1,478 & ,056 \\
\hline & Within Groups & & 7828,285 & 187 & 41,862 & & \\
\hline & Total & & 9877,279 & 221 & & & \\
\hline
\end{tabular}

Berdasarkan tabel di atas dapat diketahui bahwa nilai signifikansi sebesar 0,056. Nilai ini lebih besar dari 0,05. Hal ini berarti data kecerdasan emosi bersifat linier.

Tabel 4.1.5. hasil uji korelasi

\begin{tabular}{|c|c|c|c|c|}
\hline \multicolumn{5}{|c|}{ Correlations } \\
\hline & & kecerdasan_emosi & SLR & konsentrasi_belajar \\
\hline \multirow{3}{*}{ kecerdasan_emosi } & Pearson Correlation & 1 &, $496^{* \star}$ &,- 028 \\
\hline & Sig. (2-tailed) & &, 000 & 677 \\
\hline & $\mathrm{N}$ & 222 & 222 & 222 \\
\hline \multirow{3}{*}{ SLR } & Pearson Correlation &, 496 * & 1 &,- 079 \\
\hline & Sig. (2-tailed) & ,000 & & ,242 \\
\hline & $\mathrm{N}$ & 222 & 222 & 222 \\
\hline \multirow{3}{*}{ konsentrasi_belajar } & Pearson Correlation &,- 028 &,- 079 & 1 \\
\hline & Sig. (2-tailed) & 677 & ,242 & \\
\hline & $\mathrm{N}$ & 222 & 222 & 222 \\
\hline
\end{tabular}

Berdasarkan tabel di tabel, diketahui bahwa kecerdasan emosi tidak memiliki hubungan yang signifikan dengan konsentrasi belajar. Hal ini terlihat dari nilai $r=-0.028$, dengan nilai signifikansi $p=0.677$ ( $p>0.05)$. Selain itu, Self Regulated Learning (SRL) juga tidak memiliki hubungan yang signifikan dengan konsentrasi belajar. Dengan koefisien korelasi sebesar $r=-0.079$ dan $p=0.242$ ( $p>0.05)$. Dapat dikatakan bahwa semakin tinggi, maupun semakin rendah kecerdasan emosi subjek tidak berhubungan secara signifikan terhadap konsetrasi belajarnya. Begitupula dengan SRL, semakin tinggi maupun semakin rendah SRL yang dimiliki subjek, tidak berhubungan secara signifikan dengan konsentrasi belajarnya. Meskipun demikian, SLR dan kecerdasan emosi memiliki hubungan dengan nilai signifikansi sebesar dengan $r=0.496$ dan $p=0,000(p<0.05)$. Hal ini berarti semakin tinggi Self Reguated Learning (SLR) yang dimiliki, maka semakin tinggi pula kecerdasan emosi yang 
dimiliki seseorang. Begitu juga sebaliknya, semakin tinggi kecerdasan emosi yang dimiliki, semakin tinggi pula SLR yang dimiliki.

\section{Diskusi}

Hasil penelitian ini menunjukkan bahwa hipotesa alternatif ditolak. Hal ini berarti tidak ada hubungan yang signifikan antara self regulated learning dan kecerdasan emosi terhadap konsentrasi belajar. Secara parsial terlihat tidak terdapat hubungan yang signifikan antara self regulated learning terhadap konsentrasi belajar dengan nilai koefisien korelasi sebesar $-0,079$ $(p>0,05)$. Meskipun kemampuan SRL seseorang meningkat, namun perhatian (konsentrasi) belajar yang dimiliki tidak terjadi perubahan yang signifikan. Begitu pula dengan, kecerdasan emosi terhadap konsentrasi belajar juga tidak memiliki hubungan yang signifikan dengan nilai koefisien korelasi sebesar $-0.028(\mathrm{p}>0,05)$. Tidak adanya hubungan yang signifikan pada penelitian ini, dapat disebabkan karena beberapa hal. Hal ini disebabkan karena faktor yang mempengaruhi konsentrasi belajar pada subjek di penelitian ini bisa saja didominasi oleh faktor lain selain self regulated learning dan kecerdasan emosi. Menurut Veenstra (Nuryana dan Purwanto, 2010), faktor-faktor yang mempengaruhi konsentrasi belajar adalah a) faktor usia yakni semakin bertambah usia mempengaruhi kemampuan seseorang dalam memfokuskan perhatian; b) fisik, kemampuan fisiologis yakni sistem saraf mempengaruhi kemampuan seseorang dalam memilih informasi yang akan diperhatikannya; c) faktor pengetahuan dan pengalaman, yakni informasi yang belum dikenali sebelumnya akan lebih mudah seseorang untuk menggunakan pengalaman dan pengetahuannya untuk memahami informasi tersebut.

Selain itu, Nurul (Nuryana dan Purwanto, 2010), mengemukakan faktor lain yang mempengaruhi konsentrasi belajar yaitu suara, pencahayaan, suhu udara dan desain belajar. Dari penelitian Nuryana dan Purwanto (2010) dapat diketahui bahwa kondisi fisik lingkungan belajarlah yang mempengaruhi konsentrasi belajar. Hal ini berarti faktor eksternalah yang mempengaruhi kondisi seseorang untuk fokus dalam belajar. Sementara itu, Tabrani (Hasanah, 2015) mengemukakan bahwa faktor psikologis yang dapat mempengaruhi konsentrasi belajar adalah motivasi belajar, karakter emosi seseorang dan reaksi terhadap lingkungan.

Faktor psikologi lainnya yang mempengaruhi konsentrasi belajar seseorang adalah masalah yang dialami seseorang maupun lingkungan sekitarnya seperti masalah keluarga sehingga menurunkan atau bahkan menghilangkan semangat dan motivasi seseorang dalam belajar (Ningsih, Suranata, dan Dharsana, 2014).

Kesiapan seseorang dalam belajar, kondisi fisik (tidak sakit), kondisi psikologis (tidak stres) dan gaya belajar adalah faktor internal lain yang mempengaruhi konsentrasi belajar. 
Sementara faktor eksternal lain yang mempengaruhi konsentrasi belajar adalah yang berasal dari luar dirinya seperti suara, bau (Susanto dalam Agustini dan Sudhana, 2014).

Menurut Vroon dan Stelmach (1990) perhatian dipengaruhi oleh faktor inteligensi, biologis dan budaya. Faktor inteligensi adalah kemampuan seseorang dalam berpikir, menganalisa, membuat keputusan. Sedangkan faktor biologis adalah kondisi fisik dan genetik seseorang, seperti struktur otak, kelengkapan bagian tubuh. Jika terdapat keterbatasan pada kondisi fisik seseorang dapat mempengaruhi perhatian yang dimilikinya dalam belajar. Selain itu, gangguan pada fungsi otak atau kerusakan pada struktur otak yang dimiliki seseorang juga dapat mempengaruhi perhatian belajar yang dimiliki seseorang. Sebagai contoh adalah individu dengan retardasi mental, $A D H D$, brain injury dan autis. Dalam bukunya Plotnik \& Kouyoumdjian (2007), bahwa fungsi otak yang dimiliki individu autis berbeda dengan individu norma pada umumnya, sehingga membuat mereka memiliki perilaku dan kemampuan berpikir yang bebeda pula termasuk dalam memberikan fokus perhatian dalam belajar. Sementara, faktor budaya adalah kondisi situasi lingkungan dan kebiasaan yang dialami oleh individu (Luria, dalam Vroon \& Stelmach, 1990). Kondisi lingkungan dan kebiasaan individu dipengaruhi oleh kelompoknya. Individu yang terbiasa atau terkondisikan dilingkungan untuk memberikan perhatian yang baik dalam belajar, maka akan membuatnya lebih mudah memberikan perhatian dalam belajar. Hal ini juga sejalan dengan teori behaviorisme yang menyatakan bahwa respon individu dipengaruhi oleh stimulusnya. Jika lingkungan mendukung individu untuk fokus dalam belajar yakni lingkungan sebagai penguat, maka individu tersebut akan merespon hal yang sama yakni memberikan perhatian dalam belajar, begitu juga sebaliknya, jika lingkungan tidak mendukung atau menguatkan untuk memberikan perhatian dalam belajar maka individu tersebut juga tidak akan fokus (perhatian) dalam belajar.

Pernyataan di atas didukung dengan kondisi, subjek penelitian yang masih berada pada fase remaja akhir. Remaja akhir memiliki karakteristik yang unik. Perilaku remaja lebih mudah dipengaruhi oleh kondisi lingkungannya khususnya teman sebanyanya. Remaja lebih mampu melakukan konformitas dengan teman sebaya bila dibandingkan dengan fase perkembangan yang lain (Santrock, 2010).

Hasil penemuan lain pada penelitian ini adalah terdapat hubungan antara self regulated learning dan kecerdasan emosi dengan nilai koefisien korelasi sebesar 0,496 $(p<0,05)$. Hal ini sesuai dengan hasil penelitian Awaludin, Muthmainnah dan Ali (2014) yang menyatakan bahwa kecerdasan emosi dapat ditingkatkan melalui self regulated learning agar dapat membentuk pribadi yang utuh. Selain itu, hasil penelitian Widiyaningsih, Karyasa dan Suardana (2014) menunjukkan terdapat perbedaan antara kecerdasan emosi siswa yang belajar dengan metode self regulated learning dan siswa yang tidak menggunakan metode self regulated laerning. Selain itu, terdapat juga hubungan positif kecerdasan emosional dan 
self regulated learning pada siswa kelas XII di SMA Batik Surakarta (dalam Sari, 2017). Hasilhasil penelitian diatas memperkuat hasil tambahan pada penelitian ini bahwa self regulated learning dan kecerdasan emosi memiliki hubungan yang positif, yang berarti semakin tinggi kemampuan regulasi diri belajar seseorang maka semakin tinggi pula kecerdasan emosi yang dimilikinya.

Secara teoritis sejatinya, penelitian terkait dengan konsentrasi belajar lebih banyak dilakukan pada bidang ilmu pendidikan dan keguruan dibandingkan dibidang ilmu psikologi, sehingga teori yang ada terkait dengan konsentrasi belajarpun kurang banyak. Dalam ilmu psikologi lebih banyak dibahas tentang attention/perhatian dan rentang konsentrasi seperti dalam tes kecerdasan yang diukur melalui lamanya waktu memberikan fokus perhatian, kemampuan memahami dan mengikuti instruksi serta ketelitian dalam mengerjakan tugas. Sementara alat ukur konsentrasi belajar dalam bentuk skala sangat sedikit jumlahnya dibandingkan dengan alat ukur atau skala psikologis untuk konstruk dan variabel psikologis yang lainnya.

Penelitian ini memiliki keterbatasan yakni alat ukur yang digunakan untuk konsentrasi belajar hanya memiliki koefisien realiabilitas sedang yakni 0,798 serta validitas item sekitar $0,250-0,539$.

\section{SIMPULAN}

Berdasarkan hasil penelitian ini, dapat disimpulkan bahwa tidak terdapat hubungan yang signifikan antara self regulated learning dan konsentrasi belajar $r=-0.079(p>0,05)$, serta tidak ada hubungan yang signifikan antara kecerdasan emosi dengan konsentrasi belajar $r=$ - 0,028 ( $p>0,05)$. Hal ini berarti semakin tinggi self reguated learning yang dimiliki seseorang, tidak diikuti dengan peruahan konsentrasi belajar yang signifikan, begitu juga sebaliknya. Hal yang sama terjadi pada kecerdasan emosi, semakin tinggi skor kecerdasan emosi seseorang tidak diikuti dengan perubahan skor konsentrasi belajar yang signifikan. Di sisi lain, terdapat hubungan positif antara self regulated learning dan kecerdasan emosi maupun sebaliknya. Artinya, semakin tinggi kemampuan self regulated learning seseorang akan diimbangi dengan semakin tingginya kecerdasan emosi yang dimilikinya. Saran bagi peneliti selanjutnya adalah lebih memperhatikan validitas dan reliabilitas alat ukur yang digunakan dalam penelitian, sebaiknya meminimalkan penggunaan uji coba terpakai dalam penelitian sehingga dapat meningkatkan validitas dan reliabilitas alat ukur yang digunakan serta melakukan uji coba alat ukur terlebih dahulu sebelum melakukan pengambilan data. Saran bagi mahasiswa/pelajar, memperhatikan kondisi biologis, fisik, lingkungan dan psikologi saat belajar sehingga dapat belajar dengan lebih fokus (perhatian). Meminimalkan gangguan dalam belajar yang bisa berasal dari lingkungan sekitar, orang lain, maupun diri sendiri. 


\section{DAFTAR PUSTAKA}

Agustini, Ni Made Y.A, dan Sudhana, Hilda. (2014) Pengaruh Pemberian Aromaterapi Terhadap Konsentrasi Belajar Siswa Kelas V Sekolah Dasar Dalam Mengerjakan Soal Ulangan Umum. Jurnal Psikologi Udayana. Vol. 1 no. 2, 271-278 (2014).

Awalidun, Awaludin; Muthmainnah, Amaliah Dan Ali, Muh. Ridwan. (2014) Meningkatkan Kecerdasan Emsional Melalui Self Regulated Learning Dalam Membentuk Karakter Bangsa Yang Kuat. Jurnal Pena Vol 1 No 1 (2014).

Boekaerts, M. \& Corno, L. (2005). Self-Regulation In The Classroom: A Perspective On Assessment And Intervention. Applied Psychology: An International Review, 54(2), 199-231, 2005.

Butler, D. L. \& Winne, P.H. (1995). Feedback And Self-Regulated Learning: A Theoretical Synthesis. Review of Educational Research, 65, 245-281.

Carver, C. S., \& Scheier, M. F. (1981). Attention And Self-Regulation: A Control Theory Approach To Human Behavior. New York: Springer.

http://dx.doi.org/10.1007/978-1-4612-5887-2

Drastiana, Divy. (2016). Hubungan Antara Kecerdasan Emosi Dengan Pengambilan Keputusan Karir Pada Remaja. Skripsi. Universitas Muhammadiyah Malang.

Eisenberg, Sadovsky, \& Spinrad, 2005. Associations Of Emotion-Related Regulation With Language Skills, Emotion Knowledge, And Academic Outcomes. DOI: 10.1002/cd.143 Elpidia, N.A. (2014). Perbedaan Prestasi Akademik Mahasiswa Yang Bekerja Ditinjau Dari Self Regulated Learning. Skripsi. Universitas Muhammadiayah Malang.

Eysenck, Michael W. \& keane, Mark. (2005). Cognitive Psychology A Student's Handbook Fourth Edition. Hove and New York: Psychology Press Ltd.

Goleman, (2001). Kecerdasan Emosi untuk Mencapai Puncak Prestasi. Alih Bahasa: Widodo, A.T. Jakarta: PT. Gramedia Pustaka Utama.

--------. (2007). Kecerdasan Emosional: Mengapa El Lebih Penting Daripada IQ. Alih Bahasa: T. Hermaya. Jakarta: PT. Gramedia Pustaka Utama.

Hasanah, Nur (2015). Konsentrasi Belajar Pada Kegiatan Origami Dengan Menggunakan Metode Demonstrasi Pada Anak Kelompok B Di TK ABA Gedongkiwo Kecamatan Mantrijeron Yogyakarta. Skripsi UNY.

Helmi, A.F. (1995). Strategi Adaptasi yang Efektif dalam Situasi Kepadatan sosial. Tesis. Yogyakarta : Program Pasca Sarjana Universitas Gadjah Mada.

Hergenhahn, B. R, \& Olson, Matthew H. (1993). An Introduction To Theories Of Learning Fourth Edition. New Jersey: Prentice-Hall.

Hewstone, M., Fincham, F.D., \& Foster, J. (2005). Psychology. USA: BLACKWELL PUBLISHING 
Hoyle, R.H. (2010). Handbook Of Personality And Self-Regulation. West Sussex, United Kingdom: A John Wiley \& Sons, Ltd., Publication.

Ladd, G. W., Herald, S. L., \& Kochel, K. P. (2006). School readiness: Are there social prerequisites?. Early Education and Development, 17(1), 115-150.

Mayer, J. D., Salovey, P., \& Caruso, D. R. (2002). Mayer-Salovey-Caruso Emotional Intelligence Test (MSCEIT) User's Manual. Toronto: Multi-Health Systems.

Mole, C. (2011). Attention Is Cognitive Unison, An Essay In Philosophical Psychology. New York: Oxford University Press, Inc.

Ningsih, luh P.A.W; Suranata, Kadek dan Dharsana, Ketut. (2014). Penerapan Konseling Eksistensial Humanistik Dengan Teknik Meditasi Untuk Meningkatkan Konsentrasi Belajar Pada Siswa Kelas X TITL 3 SMK Negeri 3 Singaraja. E-jurnal Undiksa Jurusan Bimbingan Konseling vol 2, no 1 (2014).

Noor, Julliansyah. (2014). Metodologi Penelitian: Skripsi, Tesis, Disertasi Dan Karya IImiah Edisi Pertama. Jakarta: Kencana Prenadamedia Group.

Nuryana, Aryati dan Purwanto, Setiyo. (2010). Efektivitas Brain Gym Dalam Meningkatkan Konsentrasi Belajar Pada Anak. Doi: http://dx.doi.org/10.23917/indigenous.v12i1.1558

Panjaitan, Lidya Kemala Sari \& Cahyadi, Surya. (Nd). Hubungan Achievement Emotions Dan Self-Regulation Mahasiswa Dalam Mengerjakan Skripsi.

Patton, P. (1998). Emotional Intelligence. Alih Bahasa: Zaini Dahlan. Jakarta: Pustaka Delapratasa.

Pekrun, R. (2014). Emotions and Learning. International Academy of Education. Australia : International Bureau of Education.

Perry, N.E., Phillips, L., \& Hutchinson, L.R. (2006). Preparing Student Teachers To Support For Self-Regulated Learning. Elementary School Journal, 106, 237-254.

Plotnik, Rod \& Kouyoumdjian, Haig. (2011). Introduction to Psychology. Canada: Wadsworth | Cengage Learning.

Santrock, John. W. (2010). Lifespan Development Thirteenth Edition. New York: McGraw Hill. Sari, Astika Permata (2017) Hubungan Anatara Kecerdasan Emosi Dan Dukungan Sosial Dengan Self Regulated Learning Siswa Kelas XII Di SMA Batik 1 Surakarta. Thesis. UNS.

Stough, C., Saklofske, A.H., \& James Parker, D.A. (2009). Asseeing Emotional Intelligence, Theory, Reseach And Applications. Springer Dordrecht Heidelberg London New York. DOI 10.1007/978-0-387-88370-0.

Vroon, P.A. \& Stelmach, G.E. (1990). The Development Of Attention Reasearch And Theory. NORTH-HOLLAND :ELSEVIER SCIENCE PUBLISHERS B.V 
Widiyaningsih, Ni Nyoman; Karyasa, i Wayan; dan Suardana, I Nyoman. (2014). Pengaruh Model Self Regulated Learning Terhadap Kemampuan Pemecahan Masalah Dan Kecerdasan Emosiona Siswa SMA. Jurnal Penelitian Pascasarjana Undiksha vol 4 no 1 (2014).

Winne, P.H. \& Perry, N.E. (2000). Measuring self-regulated learning. In P. Pintrich, M. Boekaerts, \& M. Seidner (Eds.), Handbook of self-regulation (p. 531-566). Orlando, FL: Academic Press.

Winarsunu, Tulus. (2002). Statistik Dalam Penelitian Psikologi dan Pendidikan. Malang : UMM Press.

Zimmerman, B.J. (2002). Becoming A Self-Regulated Learner : An Overview. Theory Into Practice, Vol 41, Number 2. College of Education, The Ohio State University.

Zimmerman, B.J. (1990). Self-regulated learning and academic achievement: An overview. Educational Psychologist, 25, 3-17.

Zimmerman, B.J. (1989). A Social Cognitive View Of Self-Regulated Academic Learning. Journal Of Educational Psychology, September 1, 1989, Vol. 81, Issue 3

Zimmerman, B.J. (1986). Developmental Of Self-Regulated Learning: Which Are The Key Subproccesses? Contemporary Educational Psychology 